\title{
Wizualizacja mówienia i wielozmysłowe wspomaganie słuchania z zastosowaniem fonogestów
}

\section{Visualization of speech and multisensory support for hearing with the use of Cued Speech}

\author{
Kazimiera Krakowiak \\ Katolicki Uniwersytet Lubelski Jana Pawła II, Katedra Pedagogiki Specjalnej
}

Adres autora: Kazimiera Krakowiak, Katolicki Uniwersytet Lubelski Jana Pawła II, Katedra Pedagogiki

Specjalnej, Aleje Racławickie 14, 20-950 Lublin, e-mail: kazimiera.krakowiak@wp.pl

\begin{abstract}
Streszczenie
Warunkiem przyswojenia sobie języka dźwiękowego i nauczenia się mowy przez dziecko jest precyzyjne odróżnianie wszystkich elementarnych jednostek frazy (czyli sylab i głosek) w szybko płynącym strumieniu mowy (w ciągu fonicznym). Uszkodzenie narządu słuchu nie umniejsza wrodzonych zdolności językowych dziecka. Głębokie odbiorcze (zmysłowo-nerwowe) uszkodzenie słuchu blokuje jednak dostęp do klucza, według którego koduje się znaczenia. Dziecko głuche mimo wrodzonej zdolności do kategorialnego odróżniania elementów strumienia mowy praktycznie doświadcza afonemii lub bardzo poważnej dysfonemii, tzn. nie potrafi odróżniać i rozpoznawać słyszanych głosek tak precyzyjnie, aby przypisywać im wartość językową. Nie nabywa języka i mowy spontanicznie w codziennych konwersacjach. Nie może też z łatwością opanować umiejętności kontrolowania własnych wypowiedzi. Nie jest więc dla niego możliwe wypracowanie sobie bogatego języka. Deficyt w zakresie języka jest prawdziwą przyczyną trudności komunikacyjnych i edukacyjnych osób niesłyszących. Ten deficyt sprawia, że mają one nie tylko trudności w rozumieniu i zaburzenia mówienia, lecz także trudności w czytaniu i pisaniu. Dziecku konieczna jest pomoc w uzyskaniu dostępu do sylab, a inaczej mówiąc, konieczne jest przezwyciężenie afonemii i dysfonemii, czyli fonemizacja strumienia mowy.
\end{abstract}

Ważne jest, aby znaleźć taką metodę przezwyciężania afonemii, która będzie działać w warunkach naturalnej, swobodnej, codziennej komunikacji w rodzinie. Taką szansę daje metoda fonogestów.

Słowa kluczowe: wizualizacja mówienia • wielozmysłowe wspomaganie słuchania • fonogesty • dziecko głuche

\begin{abstract}
The first condition of language acquisition and ability to speak is to differ precisely all the elementary parts of the phrase itself (syllables and phonemes), in a quickly produced stream of speech. Hearing impairment does not diminish the child's in-born language abilities. However, severe neural and sensual hearing impairment obstructs the child's access to the key according to which the meaning of the words has been coded. A child with such an impairment, in spite of the natural ability to differentiate the elements of the stream of speech, in practice experiences aphonemy or disphonemy - he/she cannot differentiate the phonemes he/she hears in such a precise way so as to assign them the language value. A deaf child does not learn language and speech spontaneously, in everyday conversations, but he/she has to struggle for learning each particular word and learn consciously how to control his/her own speech. It is difficult for him/her to create a rich inner language and in consequence he/she experiences social, educational and communicative difficulties, and what is more, it is difficult for her/him to learn to read and write. Because of the reasons mentioned above it is important to find a method that enables to fight the aphonemy and disphonemy and which makes it possible to communicate freely and spontaneously in everyday family life and in educational settings. Cued Speech is an example of such a method.
\end{abstract}

Key words: visualization of speech $\bullet$ multisensory support for hearing $\bullet$ Cued Speech $\bullet$ deaf child

Wstęp

Na początku, po otrzymaniu diagnozy o uszkodzeniu słuchu u dziecka, rodzice martwią się, że ich córka lub syn nie może usłyszeć odgłosów świata. Zastanawiają się, czy usłyszy kiedyś dźwięki świata przyrody: śpiew ptaków, plusk wody, szmer liści, brzęczenie muchy, buczenie trzmiela. Wyobrażają sobie smutek jego życia z powodu braku 
muzyki i śpiewu. Obawiają się kłopotów wynikających z tego, że może nie usłyszeć domofonu, gwizdania czajnika, sygnału telefonu, klaksonu samochodowego, syreny pogotowia ratunkowego, syreny alarmowej. Mają nadzieję, że zastosowanie aparatów słuchowych lub implantów ślimakowych da dziecku dostęp do świata dźwięków, pozwoli usłyszeć śpiew słowika, a nawet, jak chrząszcz brzmi w trzcinie. Nie od razu uświadamiają sobie, że najważniejsze jest pytanie o to, czy dziecko słyszy głos ludzki i dźwięki mowy oraz jak je słyszy. A tymczasem dokładne, precyzyjne odróżnianie dźwięków mowy stanowi warunek konieczny rozwoju umiejętności komunikowania się z innymi ludźmi w języku fonicznym, czyli w taki sposób, jak czyni to większość ludzi. Celem artykułu jest ukazanie roli wyższych czynności słuchowych, a zwłaszcza zdolności do kategorialnej fonemowej percepcji strumienia mowy, w przyswajaniu sobie języka przez dziecko i wskazanie możliwości wykorzystania fonogestów jako metody wspomagania słuchania, odczytywania $z$ ust i mówienia.

\section{Rozwój wyższych czynności słuchowo- -językowych jako warunek przyswojenia sobie przez dziecko języka}

Warunkiem przyswojenia sobie języka dźwiękowego i nauczenia się mowy przez dziecko jest precyzyjne odróżnianie wszystkich elementarnych jednostek frazy (czyli sylab i głosek) w szybko płynącym strumieniu mowy (w ciągu fonicznym). Badania $\mathrm{z}$ zakresu psycholingwistyki rozwojowej [zob. Gleason, Ratner, 2005] wykazały, że dzieci rodzą się nie tylko ze zdolnością do prostej zmysłowej reakcji na dźwięki, lecz także z gotowością do wyższych czynności słuchowych. Zbadano to przy zastosowaniu pomysłowych procedur obserwacji reagowania niemowląt na zmiany bodźców. Mając 4 dni, noworodki odróżniają wypowiedzi w języku swoich matek (macierzystym, ojczystym) od wypowiedzi w języku obcym. Niemowlęta w pierwszych miesiącach życia są też słuchaczami uniwersalnymi, ponieważ mają zdolność do uczenia się odróżniania głosek innych języków. Czynią to $\mathrm{z}$ większą łatwością niż dzieci starsze i dorośli, bo ci ostatni wprawdzie doskonale odróżniają i rozpoznają głoski języka rodzimego, ale nie mają już wyostrzonej wrażliwości na różnice między dźwiękami języków obcych. Natomiast niemowlęta odróżniają głoski wszystkich języków.

Percepcja dźwięków mowy u niemowląt od samego początku ma charakter kategorialny, umożliwiający poznawanie językowej wartości głosek. To znaczy, że ich wrażliwość neurosensoryczna jest niejako ukierunkowana na spostrzeganie tych różnic i podobieństw między dźwiękami mowy, które są ważne dla rozpoznawania słów i zdań. Można zatem powiedzieć, że dysponują bazą neurosensoryczną do rozwoju funkcji słuchu fonemowego (fonematycznego). Ona stanowi biologiczne podłoże rozwoju czynności językowych. Dzięki niej dzieci mogą uważnie wsłuchiwać się w wypowiedzi otaczających je osób i zapamiętywać brzmienie powtarzających się w nich sekwencji dźwięków. Wsłuchują się również w sekwencje dźwięków wydawanych przez samych siebie. Najpierw, w pierwszych miesiącach życia, wydają je przypadkowo i mimowolnie (głużą), a następnie wypróbowują swoje zdolności coraz bardziej świadomie, gaworząc i wmawiając pierwsze słowa. To pozwala im bardzo szybko opanować cały repertuar wzorcowych głosek - najpierw słyszanych, a potem wymawianych - w ich typowych dla języka rodzimego połączeniach, które ustawicznie powtarzają się i wymieniają zgodnie z prawidłowościami fonotaktycznymi (dotyczącymi częstości występowania i łączliwości głosek) oraz morfonologicznymi (dotyczącymi przekształceń fonologicznych w obrębie elementarnych jednostek mających znaczenie, czyli morfemów). Niemowlęta bardzo szybko przyswajają sobie te prawidłowości [zob. Gleason, Ratner, 2005]. Dzięki temu strumień wypowiedzi staje się dostępny dla ich wyższych czynności percepcyjnych, opartych nie tylko na samym słuchaniu, lecz także na polisensorycznej integracji spostrzeżeń słuchowych, dotykowych, prioprioceptywnych i wzrokowych. To na tej bazie rozwija się zdolność błyskawicznego rozpoznawania w szybko płynącym strumieniu mowy głosek i sylab realizujących wzorce słów złożonych z fonemów i dochodzi do nadania dźwiękom mowy wartości językowej.

Na doświadczeniu polisensorycznym opiera się proces przypisywania słowom znaczeń i odkrywania ich przydatności w interakcjach z najbliższymi osobami. Percepcja sygnałów mowy nie ogranicza się bynajmniej do samego słuchania, ale jest czynnością złożoną, angażującą rozległe obszary układu nerwowego. Zanim dziecko nauczy się rozumieć wypowiedzi, w jego mózgu muszą wytworzyć się sieci połączeń neuronalnych, które w przyszłości zagwarantują mu pełne zautomatyzowanie czynności słuchania i rozumienia, jak również tworzenia wypowiedzi i mówienia, które są z rozumieniem ściśle zintegrowane. Dostęp do treści wypowiedzi i do znaczenia poszczególnych jednostek systemu językowego dziecko uzyskuje, pozostając ustawicznie w interakcjach z mówiącymi osobami dorosłymi, dojrzałymi pod względem językowym, bawiąc się i rozmawiając o tym wszystkim, co dzieje się między nimi i obok nich, w toku naturalnej działalności życiowej. Najczęściej towarzyszy temu atmosfera emocjonalna nacechowana miłością i życzliwością ze strony dorosłych oraz wrażliwością i radosną ciekawością świata ze strony dziecka.

Niemowlęta od urodzenia $\mathrm{z}$ większym zainteresowaniem słuchają strumienia wypowiedzi podzielonego na odcinki frazowe, niż takiego, który został podzielony na przypadkowe fragmenty [zob. Gleason, Ratner, 2005]. To znaczy, że ich wrażliwość jest też nastawiona na spostrzeganie melodii i rytmu mowy. Dlatego przyswajają sobie język w sposób naturalny tylko wtedy, gdy ich rozmówcy mówią w sposób ekspresyjny, zachowując intonację, akcent wyrazowy oraz logiczny i emocjonalny, zmiany tempa mówienia i barwy głosu. Ważne jest też, aby dorośli posługiwali się kodem rozwiniętym, czyli językiem dobrze dostosowanym do opisywania otaczającej rzeczywistości, nie nadmiernie uproszczonym, wystarczająco bogatym do tego, aby dziecko mogło przyswoić sobie pełny system, z jego bogatym zasobem leksykalno-semantycznym oraz kompletnym zbiorem zasad łączenia wyrazów w zadania, z zachowaniem poprawnej składni i fleksji.

\section{Uszkodzenie narządu słuchu jako przyczyna zablokowania wyższych czynności słuchowo-językowych}

Uszkodzenie słuchu nie umniejsza wrodzonych zdolności językowych dziecka. Głębokie odbiorcze 
(zmysłowo-nerwowe) uszkodzenie słuchu blokuje jednak dostęp do klucza, według którego koduje się znaczenia. Dziecko niesłyszące $\mathrm{z}$ aparatem słuchowym lub implantem ślimakowym słyszy głos, ale w niepełnej postaci, więc nie jest w stanie błyskawicznie odróżniać sylab. Mimo wrodzonej zdolności do kategorialnego odróżniania elementów strumienia mowy praktycznie doświadcza afonemii lub bardzo poważnej dysfonemii ${ }^{1}$, tzn. nie potrafi odróżniać i rozpoznawać słyszanych głosek tak precyzyjnie, aby przypisywać im wartość językową. Musi się tej umiejętności bardzo długo uczyć, wykonując żmudne i nużące ćwiczenia. Dlatego nie może przyswajać sobie słów w toku ożywionych radością i ciekawością rozmów z dorosłymi. Poszczególne słowa odbiera jako podobne do siebie, trudne do odróżnienia. Musi z wielkim wysiłkiem koncentrować się na tych różnicach, aby uczyć się pojedynczych słów. Trudno mu zachować w pamięci całe sekwencje słów, ponieważ odbiera je jako mało zróżnicowane. Nie może też z łatwością opanować umiejętności kontrolowania własnych wypowiedzi. Nie jest więc dla niego możliwe wypracowanie sobie bogatego języka. Deficyt w zakresie języka jest prawdziwą przyczyną trudności komunikacyjnych i edukacyjnych osób niesłyszących. Ten deficyt sprawia, że mają nie tylko trudności w rozumieniu i zaburzenia mówienia, lecz także trudności w czytaniu i pisaniu. Dziecku konieczna jest pomoc w uzyskaniu dostępu do sylab, a inaczej mówiąc, konieczne jest przezwyciężenie afonemii i dysfonemii, czyli fonemizacja strumienia mowy.

Koncentrując się na zaufaniu do nowoczesnych protez i na dążeniu do usprawniania działania samego narządu słuchu, bardzo łatwo uwierzyć, że poprawa słyszenia będzie wystarczająca do tego, aby dziecko mogło funkcjonować tak, jak osoby słyszące. Kiedy osiągnięcia dziecka nie są zadowalające, poddajemy je coraz silniejszej presji, intensyfikując ćwiczenia. Tymczasem dziecko doświadcza trudności, które bardzo często prowadzą do zakłóceń w komunikowaniu się w rodzinie i w szkole, i mogą przyczynić się do poważnych konsekwencji w sferze rozwoju psychicznego, zwłaszcza emocjonalnego. Atmosfera nadmiernego wysiłku i pośpiechu w działaniach rehabilitacyjnych nie pozwala rodzicom wyzwolić się z traumy, a dziecko stopniowo wprowadza w nasilającą się frustrację. Ważne jest, aby znaleźć metodę przezwyciężania afonemii, taką, która będzie działać w warunkach naturalnej, swobodnej, codziennej komunikacji w rodzinie. Taką szansę daje metoda fonogestów.

\section{Wychowanie słuchowo-językowe $\mathrm{z}$ zastosowaniem fonogestów}

Metoda fonogestów, znana na świecie pod nazwą Cued Speech, powstała w Stanach Zjednoczonych w 1964 roku. Jej twórca, R. Orin Cornnett (1913-2002), zrealizował pragnienie wielu wcześniej działających specjalistów, którzy dostrzegali potrzebę wspomagania komunikacji gestami ułatwiającymi rozpoznawanie dźwięków mowy za pomocą wzroku. Takiej metody poszukiwał na początku XIX w. polski lekarz, Jan Siestrzyński (1788-1824), tworząc metodę „znaków ręczno-ustnych” [1920; zob. Krakowiak, 2001].
Taki sposób postępowania projektował również Aleksander Graham Bell ${ }^{2}$, którego doświadczenie w komunikowaniu się z osobami z uszkodzonym słuchem było połączone $\mathrm{z}$ miłością do nich, ponieważ jego matka i żona były osobami z uszkodzonym słuchem [Cornett, 1990; s. 23]. Obecnie metoda Cued Speech służy osobom z uszkodzonym słuchem na całym świecie. Opracowano ją dla ponad sześćdziesięciu języków [Cornett, Daisey, 2009]. Polska wersja została opracowana przez autorkę niniejszego artykułu w 1984 roku [Krakowiak, 1989, 1995, 2006, 2008; Krakowiak, Sękowska, 1996; Leszka, 2006; Białas, 2007].

Fonogesty są to dyskretne ruchy jednej ręki (prawej lub lewej), towarzyszące głośnemu i wyraźnemu mówieniu. Wizualizacja mówienia polega na uzupełnianiu widocznych (dostępnych dla wzroku) ruchów artykulacyjnych narządów mowy ruchami ręki, które dopełniają ich strumień tylko w takim stopniu, w jakim jest to konieczne do precyzyjnego odróżniania i rozpoznawania wszystkich następujących po sobie elementów oralnej realizacji znaków językowych, a więc do odróżniania i rozpoznawania sylab i głosek. Fonogesty nie zastępują samych głosek, ani ich cech dystynktywnych. Z lingwistycznego punktu wiedzenia można powiedzieć, że wzbogacają wiązkę cech dystynktywnych głosek, ułatwiając ich kategoryzację i rozpoznawanie (szerzej o tych zagadnieniach: zob. Krakowiak, 2004a, 2004b).

Fonogesty pomagają usłyszeć i odczytać z ust wszystkie rzeczywiste składniki ciągu mowy, głoska po głosce, z uwzględnieniem sylab, akcentu i naturalnego, zmiennego tempa mowy. Nie zastępują mowy i nie odwracają uwagi od słuchania. Uczą uważnego wsłuchiwania się w dźwięki mowy i wpatrywania w twarz rozmówcy, ułatwiając odkrywanie różnic między głoskami oraz ich trafne rozpoznawanie i wspomagając utrwalanie w pamięci wzorców słów i zdań. „Fonogesty umożliwiają dostęp do języka 'dźwięk po dźwięku', dzięki zastosowaniu wizualnego sposobu przekazu" [Worsfold, 2009; s. 244]. Wizualizacja mowy ułatwia jej jednoczesną percepcję słuchową oraz trwałe zapamiętywanie słów: „Fonogesty pomagają uwyraźnić i skontrolować to, co usłyszane; przyspieszają uczenie się słuchania i nabywanie języka" [Smith; za: Worsfold, 2009; s. 248]. Dzięki zastosowaniu fonogestów różnice między głoskami stają się wyraziste i dzięki temu głoski mogą być rozpoznawane szybko, bezbłędnie, bez wysiłku. Dzięki nim możemy udostępnić dziecku, które słyszy dźwięki w sposób nieprecyzyjny i niekompletny, sylabiczną strukturę frazy i ukierunkować jego uwagę słuchową na to, co słyszy, tj. na językową wartość dźwięków mowy. Na tym właśnie polega wspomaganie słuchania $\mathrm{z}$ zastosowaniem fonogestów. W samych fonogestach, tzn. w konstrukcji ich systemu, zawarty jest szczegółowy i kompletny program wychowania słuchowego opracowany dla danego języka. Wskazują one bowiem na te jednostki strumienia mowy, które trzeba umieć precyzyjnie odróżnić i rozpoznawać bezpośrednio w czasie ich trwania. Dzięki temu właśnie pomagają uczyć się wsłuchiwania w dźwięki mowy. Dlatego ma słuszność Anne Worsfold, przywołując stwierdzenie terapeutów praktyków, że fonogesty i zabieg implantacji to „idealni partnerzy” (s. 244). Przyswojenie sobie języka $z$ ich zastosowaniem opiera się na ułatwieniu fonemizacji ciągu

\footnotetext{
1. Przyjmuję terminologię za Barbarą Ostapiuk (1997).

2. A.G. Bell jest znany z poszukiwania udogodnień dla ludzi z uszkodzonym słuchem. Starając się zbudować dla swojej ukochanej żony urządzenie ułatwiające słyszenie, wynalazł telefon.
} 


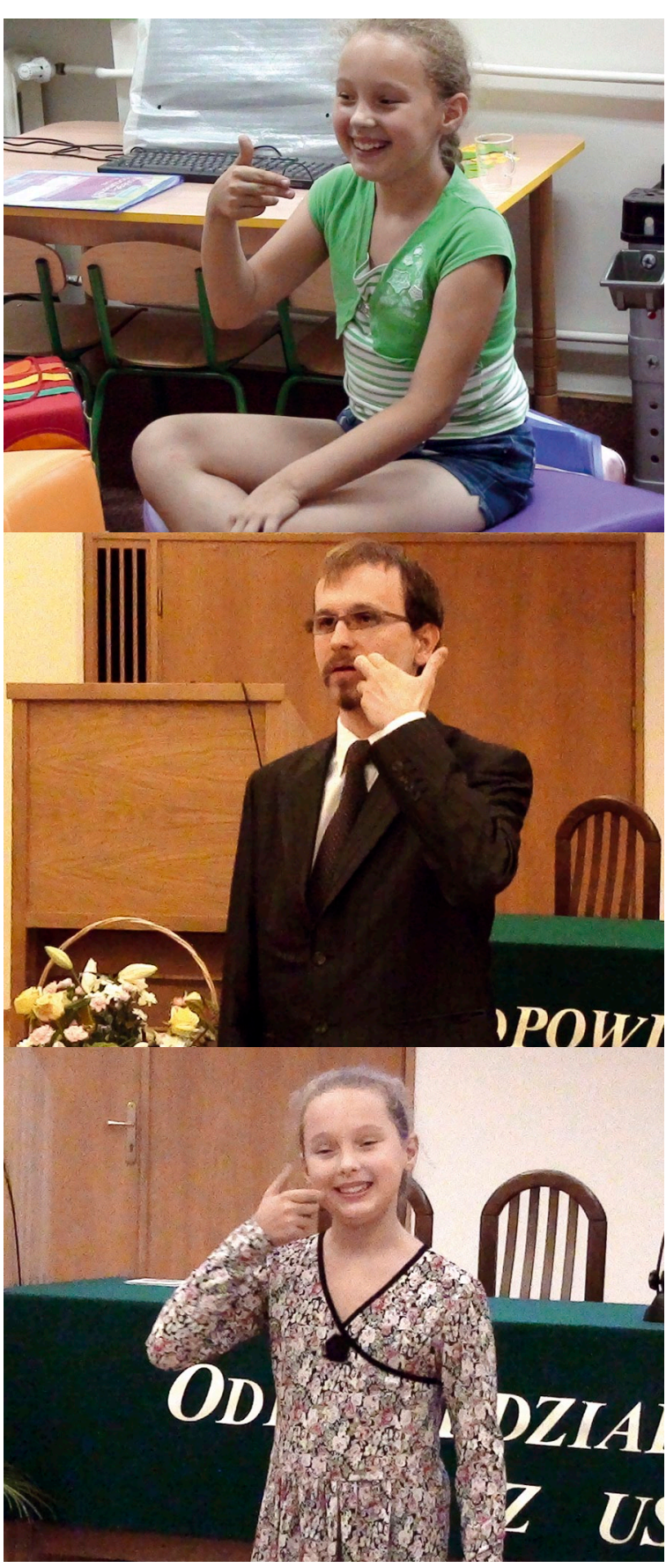

fonicznego odbieranego w sposób słuchowo-wzrokowy oraz na wspomaganiu pamięci językowej dzięki wzbogaceniu obrazów percepcyjnych i wzorców realizacyjnych wyrazów gestami uzupełniającymi, które angażują motorykę ręki i zmysł kinestetyczny. Wzbogacenie czynności mówienia przez dodanie gestów dystynktywnych wspomaga samokontrolę tej czynności. Dzięki fonogestom integracja polisensoryczno-motoryczna, dokonująca się w centralnym układzie nerwowym dziecka, prowadzi do tworzenia się w jego umyśle modeli językowych w dużym stopniu adekwatnych do języka ludzi słyszących, co w umożliwia zautomatyzowanie czynności słuchania, odczytywania $z$ ust i rozumienia, jak również tworzenia wypowiedzi i mówienia. Fakty te znalazły potwierdzenie w badaniach naukowych [Białas, 2007; Cornett, Daisey, 2009; Krakowiak, 1996; Leszka, 2006].
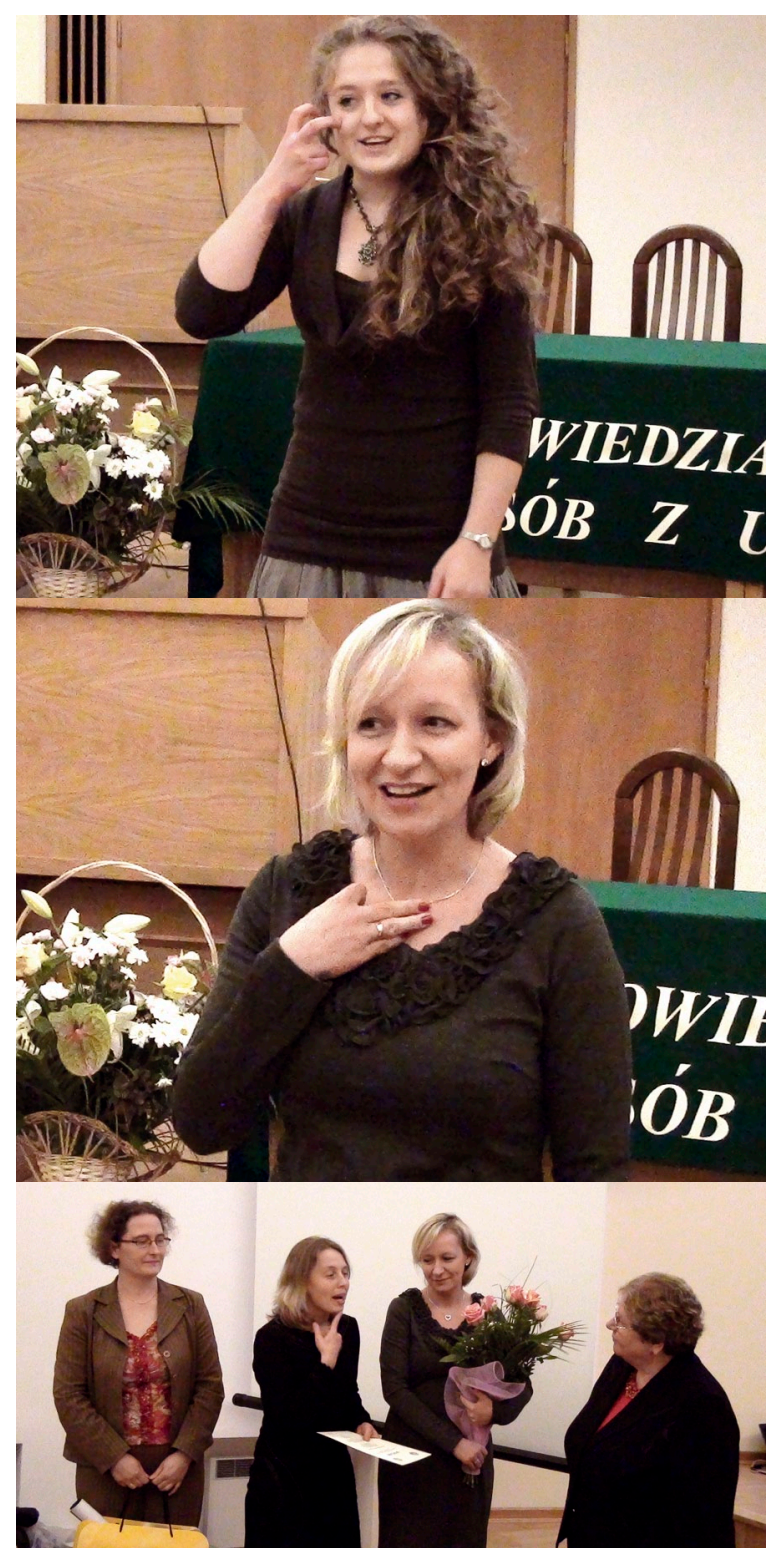

Fotografia 1. „Mówimy z fonogestami” - uczestnicy Pierwszego Ogólnopolskiego Konkursu Recytatorskiego z Fonogestami (Lublin, KUL, 27.10.2012 r.)

Z psychopedagogicznego punktu widzenia za najważniejszy walor metody fonogestów należy uznać możliwość jej stosowania w toku naturalnej działalności życiowej dziecka, we wszystkich możliwych sytuacjach codzienności, w domu, w przedszkolu, szkole. Rodzice mogą je wprowadzić, mówiąc do niemowlęcia, i używać stale aż do chwili, gdy dziecko osiągnie zdolność swobodnego rozumienia wypowiedzi bez wspomagania. Specjaliści oraz grupy wsparcia i osoby zaprzyjaźnione z niesłyszącymi mogą je stosować w każdej sytuacji, bez przeszkód i utrudnień, ponieważ używanie fonogestów nie zakłóca naturalnej komunikacji w języku dźwiękowym. Mówienie $\mathrm{z}$ fonogestami do dzieci starszych i młodzieży jest wskazane zwłaszcza wtedy, gdy język wypowiedzi zawiera nowe słownictwo oraz nowe i skomplikowane struktury składniowe, a ich treść dotyczy pojęć abstrakcyjnych i złożonych problemów. Fonogesty mogą być stosowane na każdym etapie procesu edukacyjnego, w kształceniu zawodowym, na 
uniwersytecie i w każdym miejscu, gdzie osoba niesłysząca potrzebuje pomocy w zdobywaniu nowej wiedzy lub chce uczestniczyć w dyskusji albo w innych formach wymiany myśli w grupie.

Najpełniejsze informacje o metodzie fonogestów znajdzie Czytelnik w książce Metoda fonogestów w Polsce i w Stanach Zjednoczonych. Wspomaganie rozwoju językowego dzieci i młodzieży z uszkodzonym słuchem (E. Domagała-Zyśk, 2009). Kursy metody fonogestów i egzaminy uprawniające do jej stosowania prowadzi Polskie Stowarzyszenie
Metody Fonogestów ${ }^{3}$. Opanowanie sztuki mówienia $\mathrm{z}$ fonogestami nie jest trudne, ale wymaga otwartości, życzliwości i pewnej ofiarności ze strony osób słyszących. Podstawowych umiejętności można nauczyć się pod kierunkiem instruktora w ciągu kilku dni. Pełną wprawę i płynność mówienia osiąga się po kilku miesiącach systematycznego używania. Szansa wykorzystania tej metody w wychowaniu językowym dzieci i młodzieży z uszkodzonym słuchem zależy od postaw rodziców, terapeutów, nauczycieli oraz całych społeczności, w których wychowują się dzieci z uszkodzonym słuchem [zob. Krakowiak, 2009].

\section{Piśmiennictwo:}

1. Białas M.: Głusi, język, metafora. Rozumienie metaforycznego znaczenia wyrażeń językowych przez uczniów niesłyszących. Piotrków Trybunalski, Naukowe Wydawnictwo Piotrkowskie, 2007

2. Cornett R.O.: The Century - Old Wisdom of Aleksander Graham Bell. Volta Review, 1990; 92: 145-53

3. Cornett R.O., Daisey M.E.: Badania naukowe dotyczące fonogestów. (W): Domagała-Zyśk E. (red.). Metoda fonogestów w Polsce i w Stanach Zjednoczonych. Wspomaganie rozwoju językowego dzieci i młodzieży z uszkodzonym słuchem. Lublin, Wyd. KUL, 2009; 251-65

4. Domagała-Zyśk E. (red.): Metoda fonogestów w Polsce i w Stanach Zjednoczonych. Wspomaganie rozwoju językowego dzieci i młodzieży z uszkodzonym słuchem. Lublin, Wyd. KUL, 2009

5. Gleason J.B., Ratner N.B. (red.): Psycholingwistyka. Gdańsk, Gdańskie Wydawnictwo Psychologiczne, 2005

6. Krakowiak K.: Fonogesty - polska adaptacja cued speech. Biuletyn Audiofonologii, 1989; 1(1): 27-35

7. Krakowiak K.: Fonogesty jako narzędzie formowania języka dzieci z uszkodzonym słuchem. Komunikacja językowa i jej zaburzenia, t. 9. Lublin, Wyd. UMCS, 1995

8. Krakowiak K., Sękowska J.: Mówimy z fonogestami. Przewodnik dla rodziców i przyjaciół dzieci i młodzieży z uszkodzonym słuchem. Warszawa, WSiP, 1996

9. Krakowiak K.: Metoda fonogestów jako urzeczywistnienie myśli Jana Siestrzyńskiego. (W:) Szymerowski D. (red.). Sympozjum naukowe z okazji 80 rocznicy powstania szkoły dla niesłyszących w Wejherowie. Wejherowo, 2001; 10-25

10. Krakowiak K.: W poszukiwaniu własnej drogi wychowania dziecka z uszkodzeniem słuchu (próba oceny współczesnych metod wychowania językowego). Audiofonologia, 2002; 21: 33-53. Przedruk w: Studia i szkice o wychowaniu dzieci z uszkodzeniami słuchu. Lublin, Wyd. KUL, 2006; 135-55

11. Krakowiak K.: Rola eurytmii w komunikowaniu się. (W:) Bednarczuk L., Stachurski E., Szymański T. (red.). Annales Academiae Paedagogicae Cracoviensis, Folia 19. Studia Linguistica II. Kraków, Wydawnictwo Naukowe Akademii Pedagogicznej, 2004(a): 191-98
12. Krakowiak K.: Rola sylaby w procesie opanowywania języka przez dziecko niesłyszące. Logopedia, 2004(b); 33: 192-203

13. Krakowiak K.: Studia i szkice o wychowaniu dzieci z uszkodzeniami słuchu. Lublin, Wyd. KUL, 2006

14. Krakowiak K.: Fonogesty - metoda komunikowania się słyszących rodziców z niesłyszącymi dziećmi i budowania w dziecięcych umysłach sensoryczno-motorycznej bazy mowy. (W:) Błeszyński J.J. (red.). Alternatywne i wspomagające metody komunikacji. Kraków, Oficyna Wyd. „Impuls”, 2006; 211-41

15. Krakowiak K.: Przemiany kompetencji i postaw surdopedagogów i logopedów związane ze stosowaniem metody fonogestów. (W:) Domagała-Zyśk E. (red.). Metoda fonogestów w Stanach Zjednoczonych i w Polsce. Wspomaganie rozwoju językowego dzieci i młodzieży z uszkodzonym słuchem. Lublin, Wydawnictwo KUL, 2009; 75-95

16. Krakowiak K.: Dar języka. Podręcznik metodyki wychowania językowego dzieci i młodzieży z uszkodzeniami narządu słuchu. Lublin, Wydawnictwo Katolickiego Uniwersytetu Lubelskiego, 2012

17. Leszka J.: Wychowanie słuchowo-językowe dzieci niesłyszących z zastosowaniem fonogestów. Praca doktorska napisana pod kierunkiem dr hab. K. Krakowiak, prof. KUL w Katedrze Pedagogiki Specjalnej KUL, 2006

18. Ostapiuk B.: Zaburzenia dźwiękowej realizacji fonemów języka polskiego - propozycja terminów i klasyfikacji. Audiofonologia, 1997; 10: 117-36. Przedruk w: Logopedia, 2000; 28

19. Siestrzyński J: Teoria i mechanizm mowy z zastosowaniem do nauki czytania dla wszystkich, a do nauki wymawiania dla głuchoniemych dzieci, $\mathrm{z}$ dodaniem uwag nad sposobem nauczania tychże, mps. 1820

20. Worsfold A.: Implanty ślimakowe i fonogesty - doświadczenia międzynarodowe. (W:) Domagała-Zyśk E. (red.). Metoda fonogestów w Polsce i w Stanach Zjednoczonych. Wspomaganie rozwoju językowego dzieci i młodzieży z uszkodzonym słuchem. Lublin, Wyd. KUL, 2009

\footnotetext{
3. Kontakt: 20-827 Lublin, ul Zbożowa 61 lub przez stronę internetową www.fonogesty.org.
} 